\title{
Analisis Perubahan Penggunaan Lahan dan Arahan Pemanfaatan Ruang untuk Pertanian di Kabupaten Penajam Paser Utara, Provinsi Kalimantan Timur
}

\section{Land Use Change and Direction of Land Utilization for Agriculture in Penajam Paser Utara Regency, East Kalimantan}

\author{
Benadikta Widjayatnika $^{1^{*}}$, Dwi Putro Tejo Baskoro² \& Andrea Emma Pravitasari ${ }^{2}$ \\ ${ }^{1}$ Program Studi Ilmu Perencanaan Wilayah, Sekolah Pascasarjana, Institut Pertanian Bogor, Kampus IPB \\ Dramaga Bogor 16680; ${ }^{2}$ Departemen Ilmu Tanah dan Sumber Daya Lahan, Fakultas Pertanian, Institut \\ Pertanian Bogor, Kampus IPB Dramaga Bogor 16680; \\ "Penulis korespondensi.e-mail: benadikta10@yahoo.com \\ (Diterima: 11 Oktober 2017; Disetujui 19 Desember 2017)
}

\begin{abstract}
Penajam Paser Utara was one of the youngest regency in East Kalimantan which focused to develop agriculture sector, especially food crops. Contribution agriculture sector to Gross Regional Domestic Product (PDRB) in 2015 was in second position accounted for $20.97 \%$. This research was aimed to compile direction for agricultural land use based on actual land use, regional development index and land suitability. Land use change was obtained by overlay method within two land use map (2010 and 2016) from BPN, regional development was analyzed by skalogram method using PODES data (2011 and 2014) from BPS and land suitability was evaluated referred to FAO framework using matching method between land unit mapping based on soil map 1:50,000 from BBSDLP and criteria for specific commodities. Actual land use in Penajam Paser Utara (2016) consist of forest (32.92\%), plantation (25.51\%), industrial forest (17.09\%), bush (8.76\%) and other land use (15.72\%). Land use change pattern from 2010 to 2016 showed increasing of plantation area $(3.55 \%)$ due to forest land decreasing (1.42\%). Regional development indicated by increasing of average IPD from 21.72 (2011) to 32.04 (2014). Land suitability for agriculture was classified in S3 (marginally suitable)-N2 (permanently not suitable). Retention factors were erosion hazard (e), rooting media (r), nutrion retention ( $n$ ) and nutrient availability ( $n$ ). Available land for agriculture using largely 162,493 Ha consist of (a) plantation area largely 113,796 Ha (b) wetland crop largely 24,258 (c) dry land crop largely 15,101 Ha and (d) not suitable for agriculture largely 6,027 Ha.
\end{abstract}

Keywords: agriculture, land use change, land suitability

\begin{abstract}
ABSTRAK
Kabupaten Penajam Paser Utara merupakan salah satu kabupaten termuda di Provinsi Kalimantan Timur yang sedang berupaya mengembangkan sektor pertanian terutama subsektor tanaman pangan. Kontribusi sektor pertanian terhadap PDRB pada tahun 2015 menempati urutan kedua sebesar $20.97 \%$. Penelitian ini bertujuan untuk merumuskan arahan pemanfaatan ruang untuk pertanian dengan pendekatan penggunaan lahan, tingkat perkembangan wilayah dan kesesuaian lahan. Perubahan penggunaan lahan dianalisis dengan metode overlay antara peta penggunaan lahan 2010 dan 2016 dari BPN, tingkat perkembangan wilayah dianalisis menggunakan skalogram berdasarkan data PODES tahun 2011 dan 2014 dan evaluasi kesesuaian lahan dianalisis dengan metode matching mengacu pada kerangka FAO antara satuan peta lahan (SPL) dari peta tanah skala
\end{abstract}


1:50,000 dengan kriteria untuk komoditas tertentu. Penggunaan lahan di Kabupaten Penajam Paser Utara tahun 2016 terdiri dari hutan (32.92\%), perkebunan (25.51\%), Hutan Tanaman Industri (HTI) $(17.09 \%)$, semak $(8.76 \%)$ dan penggunaan lainnya (15.72\%). Pola perubahan penggunaan lahan selama tahun 2010-2016 mengarah pada penambahan luas perkebunan (3.55\%) yang diikuti pengurangan luas hutan (1.42\%). Perkembangan wilayah ditandai dengan peningkatan nilai IPD ratarata dari 21.72 (2011) menjadi 32.04 (2014). Kesesuaian untuk pertanian berada pada kelas S3-N2 (sesuai marjinal-tidak sesuai permanen) dengan faktor pembatas bahaya erosi (e), hambatan perakaran (r), retensi hara (f) dan hara tersedia (n). Luas wilayah yang tersedia untuk pertanian adalah 162,493 ha dengan rincian (a) seluas 113,796 ha diarahkan untuk perkebunan prioritas I (b) seluas 24,258 ha untuk tanaman pangan lahan basah prioritas I (c) seluas 15,101 ha untuk tanaman pangan lahan kering dan (d) seluas 6,037 ha tidak sesuai untuk penggunaan pertanian.

Kata kunci : pertanian, perubahan penggunaan lahan, kesesuaian lahan.

\section{PENDAHULUAN}

Kabupaten Penajam Paser Utara merupakan salah satu kabupaten termuda di Provinsi Kalimantan Timur yang sedang berupaya mengembangkan sektor pertanian terutama pada subsektor tanaman pangan. Kontribusi sektor pertanian terhadap PDRB Kabupaten Penajam Paser Utara tahun 2015 menempati urutan kedua setelah sektor pertambangan dan penggalian yaitu sebesar 20.98\% (BPS Kabupaten Penajam Paser Utara 2016). Hal tersebut didukung dengan ditetapkannya lahan seluas 12,534 Ha sebagai lahan pertanian pangan berkelanjutan (LP2B). Meski demikian, pengembangan sektor pertanian di kabupaten ini masih belum optimal yang disebabkan oleh rendahnya produktivitas dan kualitas produk, terbatasnya jaringan pemasaran dan besarnya lahan potensial yang kurang dimanfaatkan (Purwantiningdyah dan Hidayanto, 2015).

Meskipun relatif baru berdiri, Kabupaten Penajam Paser Utara mengalami peningkatan jumlah penduduk (1.39\% per tahun) yang diikuti oleh perkembangan perekonomian dan wilayahnya. Hal tersebut ditandai oleh perkembangan sektor pertambangan dan perkebunan khususnya kelapa sawit. Pada tahun 2016, luas areal perkebunan kelapa sawit mencapai 47,162 ha dengan jumlah produksi sebesar 453,259 ton (Disbun Penajam Paser Utara 2017).

Perubahan penggunaan lahan tidak dapat dipungkiri merupakan salah satu bentuk konsekuensi dari adanya pertumbuhan dan perkembangan di suatu wilayah. Penggunaan lahan yang tidak sesuai dengan potensi lahan akan menyebabkan terjadinya degradasi lingkungan. Bagi sektor pertanian, penggunaan lahan yang tidak sesuai dengan potensi dapat menurunkan produktivitas hasil. Oleh karena itu diperlukan suatu arahan dalam penggunaan dan pemanfaatan lahan terutama dalam mendukung keberadaan sektor pertanian dan meningkatkan produktivitas pertanian di kabupaten ini. Arahan pemanfaatan ruang disusun berdasarkan konsep bahwa penggunaan lahan yang sesuai dengan potensi yang dimilikinya akan berlangsung secara lestari tanpa menimbulkan kerusakan lingkungan. Adapun tujuan dari penelitian ini adalah:

1. Menganalisis perubahan penggunaan lahan dari tahun 2010 sampai 2016

2. Menganalisis tingkat perkembangan wilayah tahun 2011sampai 2014

3. Menganalisis kesesuaian lahan untuk pertanian

4. Merumuskan arahan pemanfaatan ruang untuk pertanian 


\section{METODE PENELITIAN}

Penelitian dilaksanakan pada bulan Mei hingga September 2017 di Kabupaten Penajam
Paser Utara, Provinsi Kalimantan Timur. Letak geografis wilayah penelitian adalah $116^{\circ} 19^{\prime} 30^{\prime \prime}-$ $116^{\circ} 56^{\prime} 35^{\prime \prime}$ Bujur Timur dan 0048'29"-01'36'37" Lintang Selatan [Gambar 1].

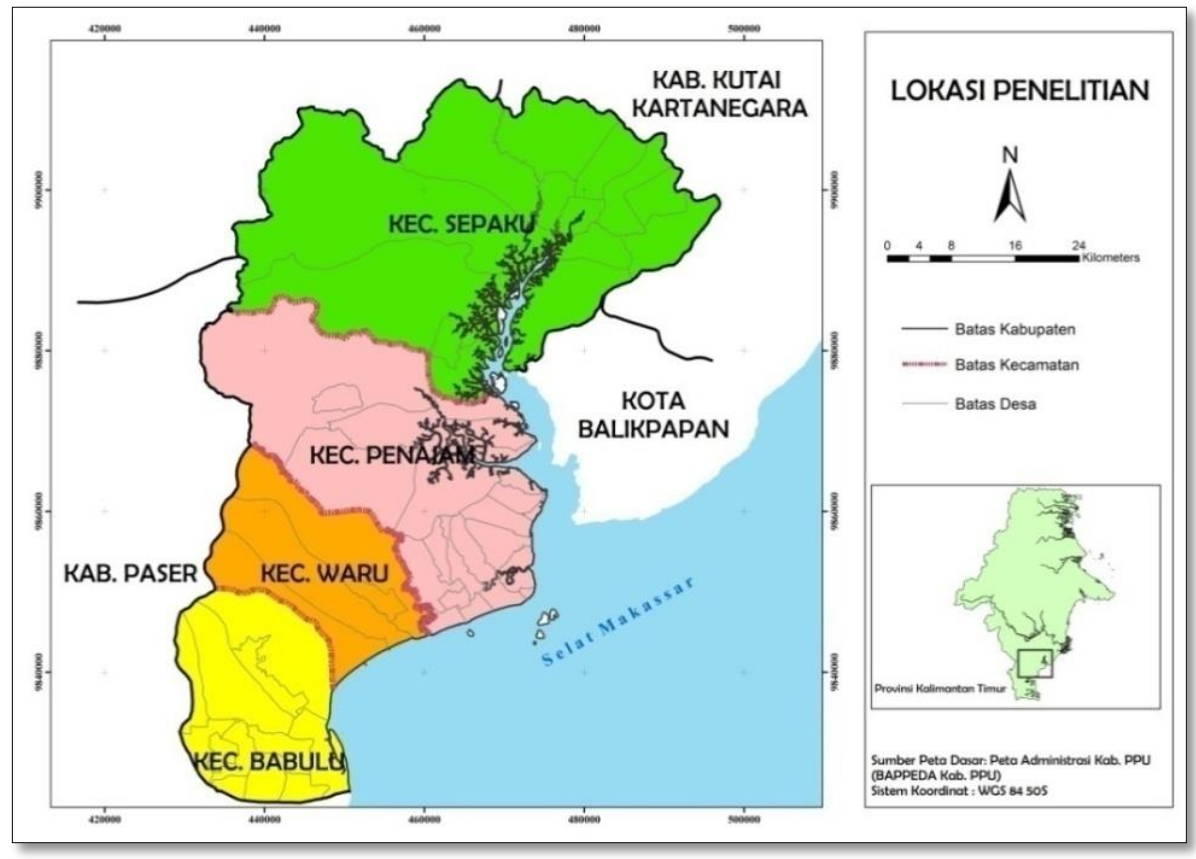

Gambar 1. Peta administrasi wilayah penelitian

Kabupaten Penajam Paser Utara terdiri atas 5 kecamatan dan 54 desa dengan Kecamatan Penajam sebagai pusat pemerintahan dan ibukota kabupaten memiliki jumlah penduduk terbanyak yaitu 74,748 jiwa. Sementara itu Kecamatan Waru merupakan kecamatan dengan jumlah penduduk paling sedikit yaitu 17,485 jiwa. Relief wilayah penelitian bervariasi dari datar hingga bergunung di mana persentase terluas $(32.77 \%$ ) adalah relief bergelombang dengan kemiringan lereng 8-15\%. Kabupaten Penajam Paser Utara memiliki lima kelompok bentuk lahan, yaitu: Aluvial (A), Marin (M), Fluviomarine (FM), Gambut (G) dan Tektonik (T). Bentuk lahan tektonik merupakan bentuk lahan dominan yang luasannya mencapai 264,299 ha atau $82.86 \%$ dengan sebaran di bagian tengah hingga barat kabupaten.

Alat yang digunakan terdiri dari seperangkat komputer, Global Positioning System (GPS), bor tanah, Soil Munsell Color
Chart dan kamera digital. Perangkat lunak (software) yang digunakan dalam mengolah data antara lain: Arc GIS 10.1, Global Mapper, Microsoft Word, dan Microsoft Excel. Bahan yang digunakan dalam penelitian ini antara lain Peta Penggunaan Tanah dari Kanwil BPN Provinsi Kalimantan Timur tahun 2011 dan 2016, Peta RTRW Kabupaten Penajam Paser Utara tahun 2011 hingga 2031, Peta Kawasan Hutan Provinsi Kalimantan Timur dan Kalimantan Utara, data PODES tahun 2011 dan 2014 dan Peta Tanah Kabupaten Penajam Paser Utara skala 1:50.000 dari BBSDLP. Teknik pengumpulan data sekunder dilakukan melalui permohonan kepada instansi terkait dan studi pustaka sedangkan pengumpulan data primer berupa data perubahan penggunaan lahan, penyebab perubahan serta karakteristik tanah di lapangan didapatkan melalui pengecekan lapang. Bagan alir penelitian disajikan pada Gambar 2. 


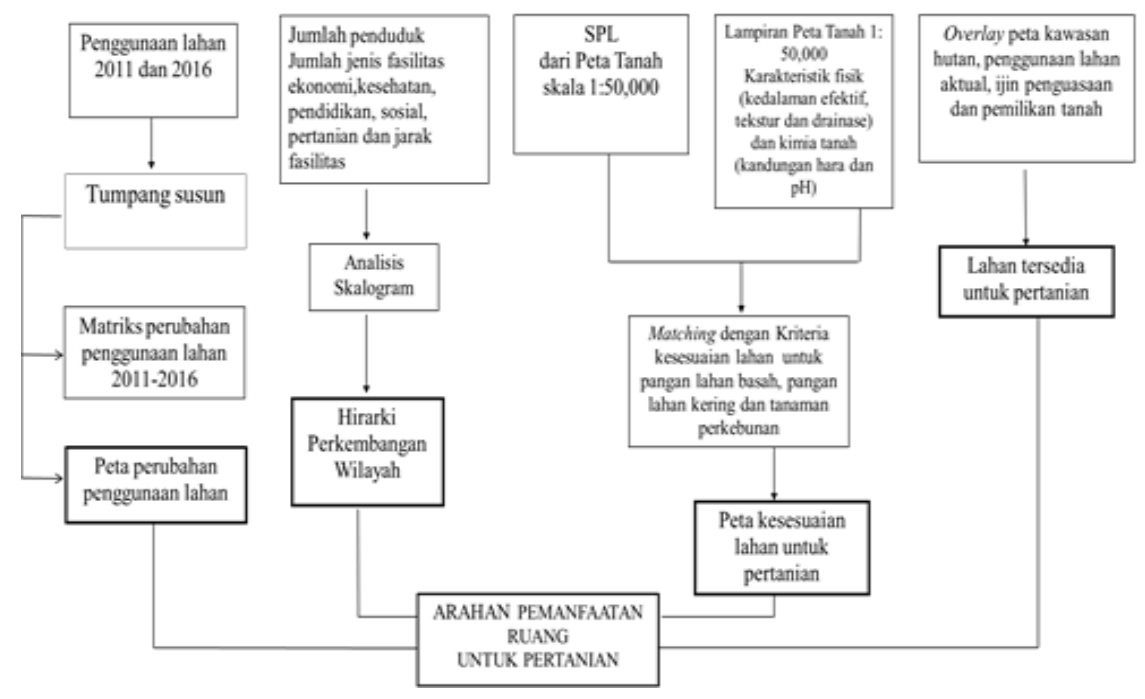

Gambar 2. Bagan alir penelitian

Analisis perubahan penggunaan lahan dilakukan dengan metode tumpang susun (overlay) antara peta penggunaan lahan tahun 2010 dan 2016 (Indrayani et al. 2017). Tahapan pertama adalah penyamaan atau koreksi koordinat antara dua peta yang digunakan kemudian dilanjutkan dengan proses overlay untuk mendapatkan data perubahan penggunaan lahan antara dua titik tahun. Pengecekan lapang dilakukan untuk memastikan jenis penggunaan lahan dan mengetahui penyebab perubahan penggunaan lahan melalui wawancara dengan masyarakat sekitar. Teknik pengecekan lapang dilakukan secara purposive sampling berdasarkan penggunaan lahan yang mengalami perubahan dan aksesibilitas untuk mencapai lokasi pengamatan. Keluaran akhir dari tahapan ini berupa matrik perubahan penggunaan lahan dan peta perubahan penggunaan lahan (Kurnianty et al.2015).

Tingkat perkembangan wilayah dianalisis dengan teknik skalogram berbobot untuk menentukan hierarki pusat-pusat wilayah penopang yang mendukung wilayah sebagai pusat pelayanan aktivitas (Ekosafitri et al. 2017). Data yang digunakan berasal dari PODES tahun 2011 dan 2014 yang terdiri dari jumlah penduduk, variabel jarak terhadap fasilitas tertentu (aksesibilitas) sebanyak 7 variabel dan 23 variabel jenis fasilitas. Variabel jenis fasilitas terdiri atas 5 fasilitas pendidikan, 6 fasilitas kesehatan, 3 fasilitas sosial dan 9 fasilitas ekonomi. Tahapan analisis skalogram menurut
Panuju dan Rustiadi (2013) terdiri dari penentuan invers jarak dengan rumus:

$$
B i j=1 / X i j
$$

$B i j=$ indeks invers data; $X i j=$ nilai data wilayah ke-i, variabel ke-j

Setelah didapatkan invers terhadap jarak kemudian dihitung kapasitas pelayanan dari fasilitas tersebut dengan rumus:

$$
\boldsymbol{A i j}=\mathbf{1 0 0 0} * \boldsymbol{F i j} / \mathbf{P i}
$$

Aij $=$ indeks fasilitas ke-j pada wilayah ke-i

Fij = jumlah fasilitas ke-j di wilayah ke-i

$\mathrm{Pi}=$ Jumlah penduduk di wilayah ke-i

Tahapan selanjutnya adalah penentuan bobot masing-masing variabel dengan rumus:

$$
\boldsymbol{I} \boldsymbol{i} \boldsymbol{j}=\boldsymbol{X} \boldsymbol{i} \boldsymbol{j} \boldsymbol{n} / \boldsymbol{X} . \boldsymbol{j} \boldsymbol{a j}
$$

$\mathrm{i}=1,2, \ldots . ., \mathrm{n} ; \mathrm{j}=$ jumlah wilayah $1,2, \ldots . ., \mathrm{n}$

Tahapan akhir dari analisis ini adalah menyusun nilai IPD dengan rumus:

$$
K \boldsymbol{i} \boldsymbol{j}=\frac{\mathrm{Iij}-\min (\mathrm{I}) \mathbf{j}}{S \mathbf{j}}
$$

$\mathrm{K}_{\mathrm{ij}}=$ nilai baku indeks hierarki

$\mathrm{I}_{\mathrm{ij}} \quad=$ nilai bobot indeks penciri wilayah

ke-1 dan ciri ke-j

$\operatorname{Min}(I)_{j}=$ nilai minimum indeks pada ciri ke- $\mathrm{j}$

$\mathrm{S}_{\mathrm{j}} \quad=$ nilai standar deviasi

Nilai IPD kemudian diurutkan menjadi hierarki dari nilai tertinggi sampai terendah dengan asumsi penetapan mengikuti sebaran normal sebagai berikut: 
Wilayah Hierarki I (berkembang) yaitu wilayah yang nilai jumlah indeks bakunya paling tidak sama dengan nilai rataan ditambah dengan standar deviasi

Wilayah Hierarki II (cukup berkembang) yaitu wilayah dengan nilai indeks hierarki paling tidak sama dengan nilai rataan indeksnya

Wilayah Hierarki III (kurang berkembang) yaitu wilayah dengan nilai indeks hierarki kurang dari nilai rataan indeks di seluruh wilayah.

Evaluasi kesesuaian lahan dilakukan dengan membandingkan antara karakteristik lahan dengan kriteria berdasarkan satuan peta lahan (SPL) (Nowar et al. 2015, Singha and Swain 2016; Widiatmaka et al. 2016). Kriteria yang digunakan terdiri dari tanaman pangan lahan basah, tanaman pangan lahan kering dan tanaman perkebunan (Badan Litbang Pertanian 2012 dan Hardjowigeno dan Widiatmaka 2015) di mana kriteria tersebut mengacu pada kerangka evaluasi lahan FAO (2007). Karakteristik lahan yang digunakan antara lain media perakaran (tekstur dan drainase), retensi hara (KTK, kejenuhan basa, $\mathrm{pH}$ dan C-organik), ketersediaan hara (P2O5, K2O dan $\mathrm{N}$ total), bahaya erosi (kemiringan lereng) dan ketersediaan air (curah hujan dan jumlah bulan kering). Dengan demikian akan diperoleh kelas kesesuaian lahan untuk pertanian pada setiap satuan lahan yaitu S1 (sangat sesuai), S2 (cukup sesuai), S3 (sesuai marginal) dan N1 (tidak sesuai saat ini) dan N2 (tidak sesuai permanen). Pengelompokan kelas kesesuaian didasarkan pada faktor penghambat terberat (minimum limiting factor) yang dimiliki oleh masingmasing SPL (Lukman et al. 2017). Penyusunan arahan pemanfaatan ruang untuk pertanian dilakukan secara deskriptif dengan bantuan Sistem Informasi Geografis (SIG) dan didahului dengan analisis lahan tersedia (Sadesmesli et al. 2017; Nowar et al. 2015). Pemanfaatan ruang di kawasan hutan telah diatur oleh Kementerian Kehutanan dan Lingkungan Hidup berdasarkan peruntukan masing-masing kawasan sehingga pengembangan pertanian tidak diarahkan pada kawasan tersebut. Arahan pemanfaatan ruang untuk pertanian disusun berdasarkan pertimbangan penggunaan lahan aktual, hierarki perkembangan wilayah dan kesesuaian lahan. Apabila dalam suatu wilayah terdapat kelas kesesuaian lahan yang sama untuk beberapa komoditas maka arahan pengembangan komoditas dilihat berdasarkan kebijakan prioritas pengembangan komoditas daerah maupun nasional (Rahman et al. 2015) [Tabel 1].

Tabel 1. Matriks arahan pemanfaatan ruang untuk pertanian

\begin{tabular}{llllll}
\hline $\begin{array}{l}\text { Status kawasan/ } \\
\text { kepemilikan lahan }\end{array}$ & $\begin{array}{l}\text { Penggunaan } \\
\text { lahan }\end{array}$ & $\begin{array}{l}\text { Kesesuaian } \\
\text { lahan }\end{array}$ & $\begin{array}{l}\text { Hierarki } \\
\text { wilayah }\end{array}$ & $\begin{array}{l}\text { Ketersediaan } \\
\text { lahan }\end{array}$ & $\begin{array}{l}\text { Arahan } \\
\text { pemanfaatan }\end{array}$ \\
\hline Kawasan hutan & - & - & - & Tidak tersedia & Tidak diarahkan \\
\hline APL & $\begin{array}{l}\text { Kawasan } \\
\text { terbangun dan } \\
\text { tubuh air }\end{array}$ & - & Tidak tersedia & Tidak diarahkan \\
\hline APL, Ijin lokasi, HGU & $\begin{array}{l}\text { Hutan, semak, S3 } \\
\text { tanah terbuka }\end{array}$ & II, III & Tersedia & $\begin{array}{l}\text { Ekstensifikasi } \\
\text { prioritas I }\end{array}$ \\
\hline & $\begin{array}{l}\text { Hutan, semak, S3 } \\
\text { tanah terbuka }\end{array}$ & I & Tersedia & $\begin{array}{l}\text { Ekstensifikasi } \\
\text { prioritas II }\end{array}$ \\
\hline $\begin{array}{l}\text { Perkebunan, } \\
\text { sawah, S3 } \\
\text { tegalan, kebun } \\
\text { campuran }\end{array}$ & I, II, III & Tersedia & Intensifikasi \\
& $\begin{array}{l}\text { Semua jenis } \\
\text { penggunaan } \\
\text { lahan }\end{array}$ & N1, N2 & I, II, III & Tersedia & $\begin{array}{l}\text { Tidak diarahkan } \\
\text { untuk pertanian }\end{array}$ \\
\hline
\end{tabular}

Keterangan : APL : Area Penggunaan Lain; HPK Hutan Produksi Konversi; HP : Hutan Produksi; HGU : Hak Guna Usaha. Sumber : Balai Besar Litbang Sumberdaya Lahan Pertanian (2012) dengan modifikasi 


\section{HASIL DAN PEMBAHASAN}

\section{Perubahan Penggunaan Lahan}

Penggunaan lahan di Kabupaten Penajam Paser Utara selama rentang waktu 2010 hingga 2016 didominasi oleh hutan (32.92\%), perkebunan $(25.51 \%)$, hutan tanaman industri (HTI) $(17.09 \%)$, semak $(8.76 \%)$ dan penggunaan lahan lainnya (15.72\%). Penggunaan lahan hutan dan HTI dominan berada di Kecamatan Sepaku, sementara penggunaan lahan perkebunan tersebar di seluruh wilayah kabupaten dengan jenis komoditas antara lain adalah kelapa sawit, karet dan kelapa. Sebagai salah satu wilayah yang ditetapkan menjadi lumbung pangan di Provinsi Kalimantan Timur, penggunaan lahan sawah di Kabupaten Penajam Paser Utara belum mendominasi yaitu hanya 12,237 ha atau $3.85 \%$ dari luas wilayah. Sebagian besar sawah (70.28\%) berada di Kecamatan Babulu seluas 8,601 ha. Peta penggunaan lahan tahun 2010 dan 2016 disajikan pada Gambar 3 dan Gambar 4.

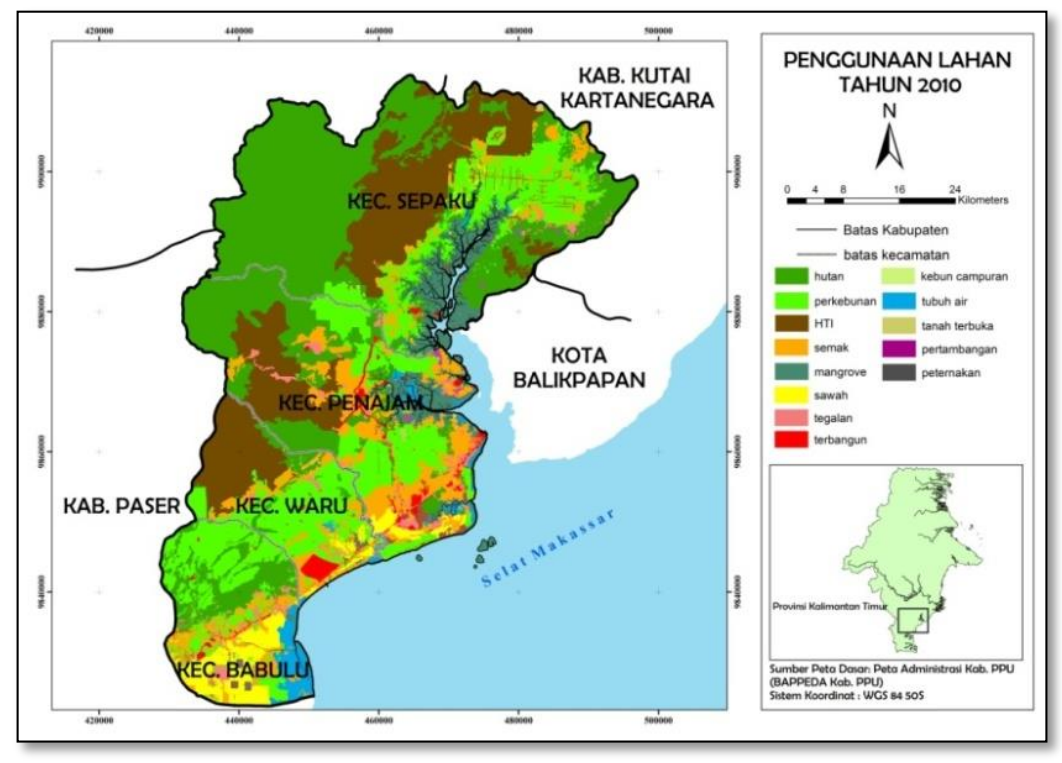

Gambar 3. Peta penggunaan lahan tahun 2010

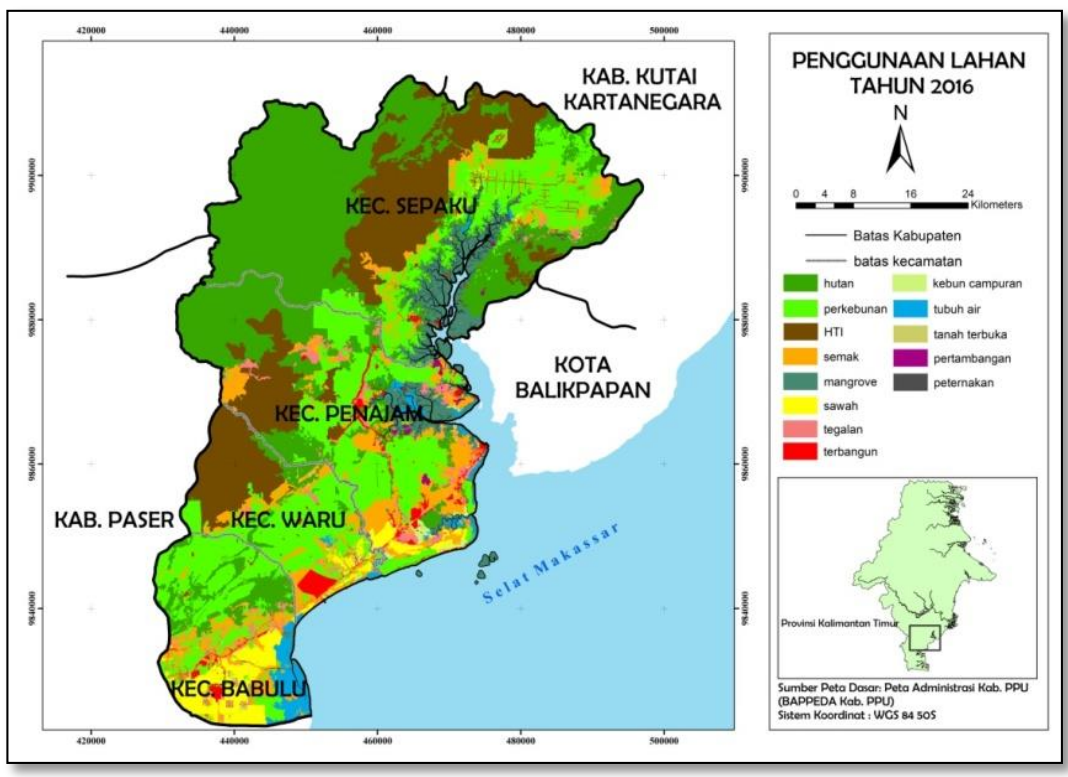

Gambar 4. Peta penggunaan lahan tahun 2016 
Penutupan/penggunaan lahan di Pulau Kalimantan khususnya Provinsi Kalimantan Timur masih didominasi oleh hutan meski luasannya telah banyak mengalami pengurangan (Rusdiana et al. 2017). Hutan mengalami pengurangan luas terbesar seluas 4,528 ha (1.42\%) dengan jenis perubahan menjadi semak dan perkebunan. Salah satu faktor yang turut berperan dalam pengurangan luasan hutan adalah adanya kebakaran yang melanda Provinsi Kalimantan Timur, termasuk Kabupaten Penajam Paser Utara pada tahun 2015. Penggunaan lahan HTI banyak berubah menjadi semak dan perkebunan yang salah satunya disebabkan berakhirnya ijin penguasaan sehingga areal tersebut dibiarkan tumbuh menjadi semak ataupun diusahakan oleh masyarakat untuk perkebunan. Perubahan penggunaan lahan dari pertanian baik lahan basah maupun lahan kering ke kawasan terbangun belum nyata terlihat pada wilayah penelitian. Hal ini diduga disebabkan Kabupaten Penajam Paser Utara masih memiliki lahan yang cukup luas sehingga perubahan penggunaan lahan cenderung terjadi pada hutan atau semak dibandingkan sawah ataupun lahan pertanian tanaman kering [Tabel 2]. Arah perubahan penggunaan lahan terpusat di Kecamatan Penajam seluas 13,487 ha yang mengarah pada peningkatan luas perkebunan seluas 11,924 ha (3.55\%). Pemusatan perubahan penggunaan lahan di Kecamatan Penajam disebabkan karena kecamatan ini merupakan pusat pemerintahan dan pusat perekonomian di kabupaten ini. Perubahan penggunaan lahan yang mengarah pada peningkatan luas perkebunan khususnya perkebunan kelapa sawit dapat berdampak pada semakin terdesaknya keberadaan lahan pertanian terutama tanaman pangan.

Tabel 2. Jenis dan luas penggunaan lahan Kabupaten Penajam Paser Utara tahun 2010-2016

\begin{tabular}{llllllll}
\hline \multirow{2}{*}{ No } & \multirow{2}{*}{$\begin{array}{l}\text { Jenis } \\
\text { lahan }\end{array}$} & & \multicolumn{2}{c}{ penggunaan } & \multicolumn{2}{c}{ Tahun 2010} & \multicolumn{3}{c}{ Tahun 2016 } & \multicolumn{3}{c}{ Perubahan luas } \\
\cline { 2 - 8 } & Ha & \multicolumn{1}{c}{ Ha } & Ha & $\%$ \\
\hline 1 & Hutan & 109,254 & 34.34 & 104,726 & 32.92 & $(4,528)$ & $(1.42)$ \\
2 & Perkebunan & 69,843 & 21.96 & 81,137 & 25.51 & 11,294 & 3.55 \\
3 & HTI & 58,132 & 18.27 & 54,353 & 17.09 & $(3,780)$ & $(1.19)$ \\
4 & Semak & 32,205 & 10.12 & 27,868 & 8.76 & $(4,338)$ & $(1.36)$ \\
5 & Mangrove & 15,030 & 4.72 & 14,975 & 4.71 & $(55)$ & $(0.02)$ \\
6 & Sawah & 12,021 & 3.78 & 12,237 & 3.85 & 217 & 0.07 \\
7 & Tegalan & 6,494 & 2.04 & 7,059 & 2.22 & 565 & 0.18 \\
8 & Tubuh air & 6,235 & 1.96 & 6,287 & 1.98 & 52 & 0.02 \\
9 & Kawasan terbangun & 6,037 & 1.90 & 6,572 & 2.07 & 535 & 0.17 \\
10 & Kebun campuran & 1,513 & 0.48 & 1,510 & 0.47 & $(4)$ & $(0.00)$ \\
11 & Tanah terbuka & 827 & 0.26 & 600 & 0.19 & $(227)$ & $(0.07)$ \\
12 & Pertambangan & 516 & 0.16 & 776 & 0.24 & 260 & 0.08 \\
13 & Peternakan & 1 & 0.00 & 10 & 0.00 & 10 & 0.00 \\
\hline
\end{tabular}

\section{Analisis Tingkat Perkembangan Wilayah}

Hasil analisis skalogram menunjukkan peningkatan rata-rata nilai IPD dari 21.72 (2011) dengan standar deviasi 7.58 menjadi 32.04 (2014) dengan standar deviasi 8.12. Peningkatan nilai rata-rata IPD ini mengindikasikan adanya perkembangan wilayah di Kabupaten Penajam Paser Utara. Nilai IPD tertinggi pada tahun 2011 dan 2014 berada pada Kelurahan Nipah-nipah dengan nilai 53.18 dan 60.60. Sementara itu nilai IPD terendah pada tahun 2011 berada di Kelurahan Jenebora yaitu sebesar 8.4. Pada tahun
2014, Kelurahan Pantai Lango memiliki nilai IPD paling rendah yaitu 16.68. Kelurahan Jenebora dan Pantai Lango memiliki IPD paling rendah dikarenakan jaraknya yang cukup jauh dari pusat pelayanan yaitu $\pm 60 \mathrm{~km}$. Sebagian besar desa/kelurahan yaitu 33 desa/kelurahan (61.11\%) di Kabupaten Penajam Paser Utara termasuk dalam hierarki III (kurang berkembang). Sebanyak 8 desa/kelurahan (14.81\%) termasuk dalam hierarki I (berkembang) dan 13 desa/kelurahan (24.07\%) termasuk hierarki II. 
Perkembangan wilayah juga dapat dilihat di Kecamatan Waru, di mana pada tahun 2011, seluruh desa/kelurahan di kecamatan ini termasuk dalam hierarki III, kemudian pada tahun 2014, Desa Sesulu mengalami peningkatan menjadi hierarki II [Tabel 3]. Meski demikian, terjadipenurunan jumlah desa di hierarki II yang diikuti penambahan jumlah desa di hierarki III. Hal ini diduga disebabkan penambahan jumlah penduduk lebih tinggi dibandingkan penambahan jumlah dan jenis fasilitas. Hierarki wilayah bersifat relatif berdasarkan perbandingan dengan wilayah di sekitarnya.

Tabel 3. Perkembangan hierarki wilayah di Kabupaten Penajam Paser Utara tahun 2011-2014

\begin{tabular}{lllllll}
\hline \multirow{2}{*}{ Kecamatan } & \multicolumn{2}{c}{ Jumlah desa tahun 2011 } & \multicolumn{4}{c}{ Jumlah desa tahun 2014 } \\
\cline { 2 - 7 } & Hierarki I & Hierarki II & Hil & Hierarki & Hierarki II & Hierarki III \\
\hline Babulu & 1 & 7 & 4 & 2 & 3 & 7 \\
Waru & 0 & 0 & 4 & 0 & 1 & 3 \\
Penajam & 2 & 6 & 15 & 2 & 6 & 15 \\
Sepaku & 4 & 9 & 2 & 4 & 3 & 8 \\
\hline Jumlah & 7 & 22 & 25 & 8 & 13 & 33 \\
Persentase & 12.96 & 40.74 & 46.30 & 14.81 & 24.07 & 61.11 \\
\hline
\end{tabular}

Jenis Tanah dan Satuan Peta Lahan (SPL)

Wilayah penelitian dikelompokkan menjadi 32 satuan peta tanah (SPL) yaitu satuan peta dengan jenis tanah, bahan induk dan bentuk lahan yang sama. Luasan SPL terbesar adalah SPL 27 dengan jenis tanah Typic Hapludult dari bahan induk batu pasir dan batu liat pada bentuk lahan dataran tektonik/struktural dengan lereng bergelombang. Luasan SPL ini adalah 70,697 Ha atau $22.34 \%$ dengan sebaran di seluruh wilayah kabupaten. Luasan SPL terkecil adalah SPL 9 seluas $231 \mathrm{Ha}(0.07 \%)$ dengan jenis tanah Typic Sulfaquents dan bahan induk endapan liat marine pada kondisi lereng datar. Kondisi drainase baik sampai sangat baik kecuali pada beberapa SPL yang tergenang seperti SPL 1,2 dan 3 yang memiliki drainase terhambat. Tekstur termasuk dalam kategori halus-sangat halus dengan kelas tekstur dominan sandy clay loam-clay loam. Terdapat kelas tektur agak kasar-kasar yaitu sandy clay pada SPL 4 yang terbentuk dari bahan induk endapan pasir. Tingkat bahaya erosi (e) bervariasi seiring dengan variasi kemiringan lereng yaitu antara datar sampai bergunung.Secara umum nilai-nilai KTK, KB dan C-organik pada wilayah penelitian tergolong rendah-sangat rendah disertai dengan nilai $\mathrm{pH}$ yang rendah-sangat rendah. Ketersediaan hara (n) atau nutrient availability ditandai dengan kandungan Nitrogen total, $\mathrm{P}_{2} \mathrm{O}_{5}$ dan $\mathrm{K}_{2} \mathrm{O}$. Secara umum, kandungan ketiga unsur ini juga berada pada kisaran rendah-sangat rendah.

\section{Kesesuaian Lahan untuk Tanaman Pangan Lahan Basah}

Wilayah yang dianalisis untuk kesesuaian lahan pertanian seluas 315,689 ha, sementara wilayah seluas 2,419 Ha tidak dianalisis karena berupa tubuh air pulau-pulau kecil [Tabel 4]. Kelas kesesuaian sangat sesuai (S1) dan cukup sesuai (S2) untuk tanaman pangan lahan basah tidak ditemukan pada wilayah penelitian. Kelas kesesuaian tertinggi adalah sesuai marjinal (S3) yaitu seluas 189,401 ha atau $60 \%$ dengan berbagai jenis dan intensitas faktor pembatas. Wilayah seluas 93,954 ha $(29.42 \%)$ termasuk kelas S3rfne yaitu sesuai marginal dengan hambatan perakaran, retensi dan ketersediaan hara serta bahaya erosi. Sementara itu wilayah seluas 126,288 Ha atau $40 \%$ dari luas wilayah tidak sesuai $(\mathrm{N})$, baik tidak sesuai saat ini maupun tidak sesuai permanen. 
Tabel 4. Kesesuaian lahan untuk tanaman pangan lahan basah

\begin{tabular}{llrl}
\hline Kelas kesesuaian & SPL & Luas $(\mathrm{Ha})$ & Persentase $(\%)$ \\
\hline S3rfne & $13,16,25,27$ & 93,594 & 29.42 \\
N2e & $19,20,21,30,31,32$ & 64,384 & 20.24 \\
N1e & $14,17,18,29$ & 59,122 & 18.59 \\
S3rfn & $6,8,15,23$ & 39,478 & 12.41 \\
S3fn & $2,7,9,11,22$ & 20,813 & 6.54 \\
S3f & $3,5,10$ & 11,635 & 3.66 \\
S3rne & 26,28 & 10,907 & 3.43 \\
S3rn & 12,24 & 9,027 & 2.84 \\
S3n & 1 & 3,947 & 1.24 \\
N1r & 4 & 2,782 & 0.87 \\
blank & - & 2,419 & 0.76 \\
\hline Jumlah & & 318,108 & 100.00 \\
\hline
\end{tabular}

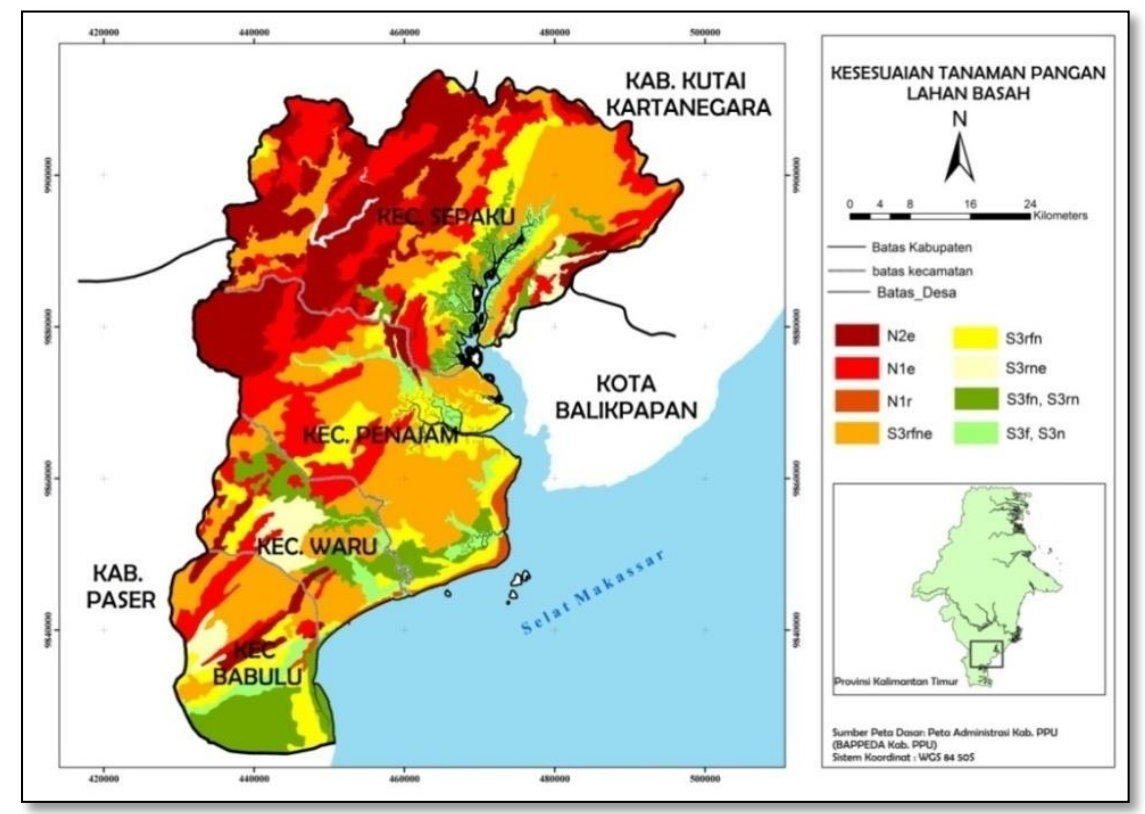

Gambar 5. Kesesuaian lahan untuk tanaman pangan lahan basah

Jenis dan intensitas faktor pembatas menentukan tindakan pengelolaan pada tiap kelas kesesuaian. Kecamatan Babulu yang merupakan sentra pertanaman tanaman pangan lahan basah di kabupaten ini memiliki lahan seluas 8,435 ha yang termasuk dalam kelas S3fn [Gambar 5]. Kelas kesesuaian dengan faktor penghambat retensi maupun ketersedian hara dapat diperbaiki dengan pemberian kapur. Oleh karena itu wilayah-wilayah dengan kelas kesesuaian ini berpotensi untuk dipertahankan sebagai lahan pertanian pangan lahan basah seperti Desa Sri Raharja dan Desa Gunung Intan. Wilayah-wilayah di Kecamatan Sepaku yang memiliki faktor pembatas berupa bahaya erosi (e) relatif lebih sulit untuk dilakukan tindakan perbaikan karena membutuhkan biaya yang cukup besar. Kecamatan Sepaku merupakan kecamatan yang memiliki luas wilayah tidak sesuai untuk tanaman pangan lahan basah paling luas yaitu 75,621 ha atau $23.89 \%$ dari keseluruhan luas wilayah yang dievaluasi. Wilayah yang termasuk dalam kelas kesesuaian N1e dan N2e sebagian besar masuk dalam kawasan hutan. Faktor pembatas utama yang menyebabkan ketidaksesuaian di kecamatan ini adalah kondisi lereng yang berkisar pada bergelombang-berbukit. 


\section{Kesesuaian untuk Tanaman Pangan Lahan Kering}

Sebagaimana hasil analisis kesesuaian untuk tanaman pangan lahan basah, kelas kesesuaian untuk tanaman lahan kering juga berada pada kelas S3 sampai dengan N2. Kelas kesesuaian lahan S1 (sangat sesuai) dan cukup sesuai (S2) tidak dijumpai pada wilayah penelitian. Kelas kesesuaian tertinggi untuk tanaman pangan lahan kering adalah sesuai marjinal, di mana S3fne adalah kelas dengan wilayah terluas yaitu 93,594 ha $(50.08 \%$ dari jumlah wilayah yang sesuai) yang disajikan pada Tabel 5.

Tabel 5. Kesesuaian Lahan untuk Tanaman Pangan Lahan Kering

\begin{tabular}{llrl}
\hline Kelas kesesuaian & SPL & Luas (Ha) & Persentase (\%) \\
\hline S3fne & $13,16,25,27$ & 93,594 & 29.42 \\
N2e & $19,20,21,30,31,32$ & 64,384 & 20.24 \\
N1e & $14,17,18,29$ & 59,122 & 18.59 \\
S3rfn & $2,3,5,6,7,8,9,10,11$ & 42,477 & 13.35 \\
S3fn & $15,22,23$ & 29,450 & 9.26 \\
S3ne & 26,28 & 10,907 & 3.43 \\
S3n & 24 & 6,522 & 2.05 \\
N1r & 4,12 & 5,287 & 1.66 \\
S3rn & 1 & 3,947 & 1.24 \\
(blank) & & 2,419 & 0.76 \\
\hline Jumlah & & 318,108 & 100.00 \\
\hline
\end{tabular}

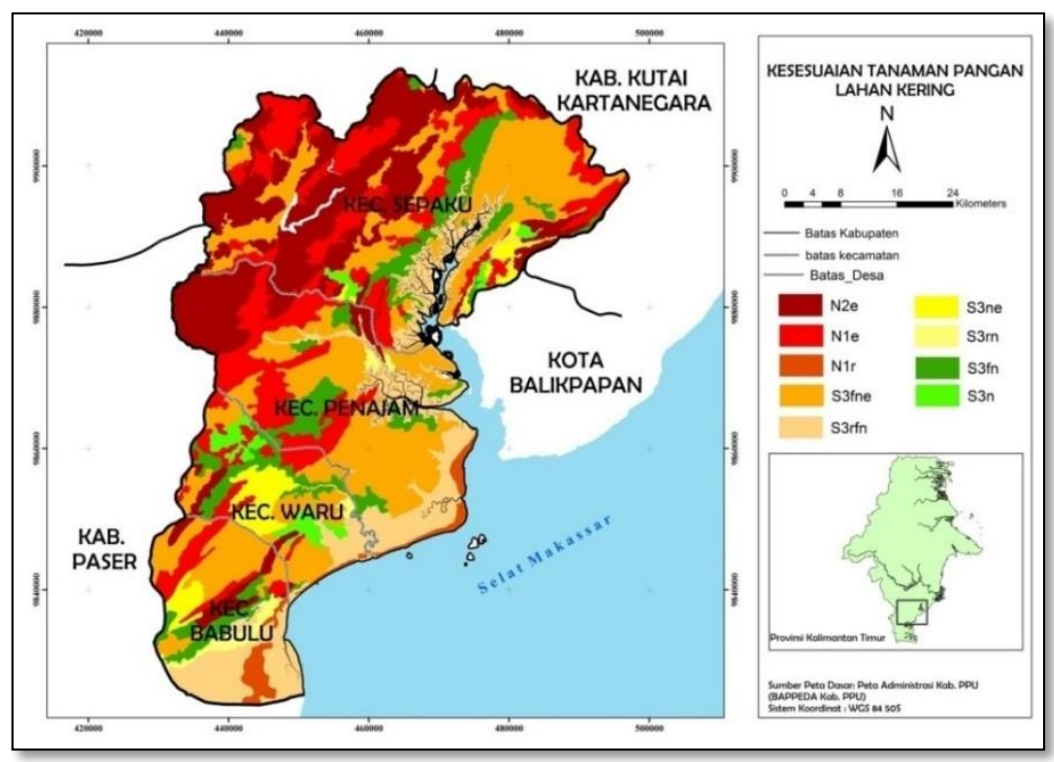

Gambar 6. Kesesuaian lahan untuk tanaman lahan kering

Sebaran kelas S3fne berada pada keempat kecamatan yang ada di kabupaten ini. Kecamatan Sepaku dan Kecamatan Penajam adalah dua kecamatan dengan proporsi luasan kelas S3fne yang paling luas yaitu 39,484 ha dan 30,527 ha. Kelas kesesuaian S3n terdapat di wilayah ini seluas 6,522 ha dan tersebar di dua kecamatan yaitu Kecamatan Waru dan Sepaku. Desa Sesulu, Desa Bangunmulyo [Gambar 6] dan Kelurahan Waru merupakan wilayahwilayah di Kecamatan Waru yang memiliki kelas S3n. Meski tidak begitu luas namun wilayah dengan kelas kesesuaian S3n lebih berpotensi untuk dikembangkan karena 
intensitas faktor penghambat yang lebih rendah dibandingkan kelas kesesuaian lainnya.

\section{Kesesuaian lahan untuk Tanaman Perkebunan}

Sebagian besar wilayah di kabupaten ini seluas 246,019 ha $(77.93 \%$ dari luas wilayah) termasuk dalam kelas kesesuaian lahan sesuai marjinal (S3). Kelas kesesuaian dengan luasan terbesar adalah S3fn seluas 119,075 ha $(48.40 \%)$ dari jumlah wilayah yang sesuai). Kelas kesesuaian ini memiliki faktor penghambat berupa retensi hara (f) dan ketersediaan hara (n). Kedua faktor penghambat ini tergolong non permanen dan dapat diperbaiki dengan tindakan penambahan kapur maupun pemupukan serta penambahan bahan amelioran seperti bahan organik [Tabel 6].

Tabel 6. Kesesuaian lahan untuk tanaman perkebunan

\begin{tabular}{llrl}
\hline Kelas kesesuaian & SPL & Luas $(\mathrm{Ha})$ & Persentase (\%) \\
\hline S3fn & $13,15,16,23,25,27$ & 119,075 & 37.43 \\
S3fne & $14,17,18,29$ & 59,122 & 18.59 \\
N1e & $19,20,21,30$ & 44,097 & 13.86 \\
S3rfn & $2,3,6,7,8,9,11,22$ & 38,399 & 12.07 \\
N2e & 31,32 & 20,287 & 6.38 \\
S3n & $24,26,28$ & 17,429 & 5.48 \\
S3rf & 5,10 & 8,047 & 2.53 \\
N1r & 4,12 & 5,287 & 1.66 \\
S3rn & 1 & 3,947 & 1.24 \\
blank & - & 2,419 & 0.76 \\
\hline jumlah & & 318,108 & 100.00 \\
\hline
\end{tabular}

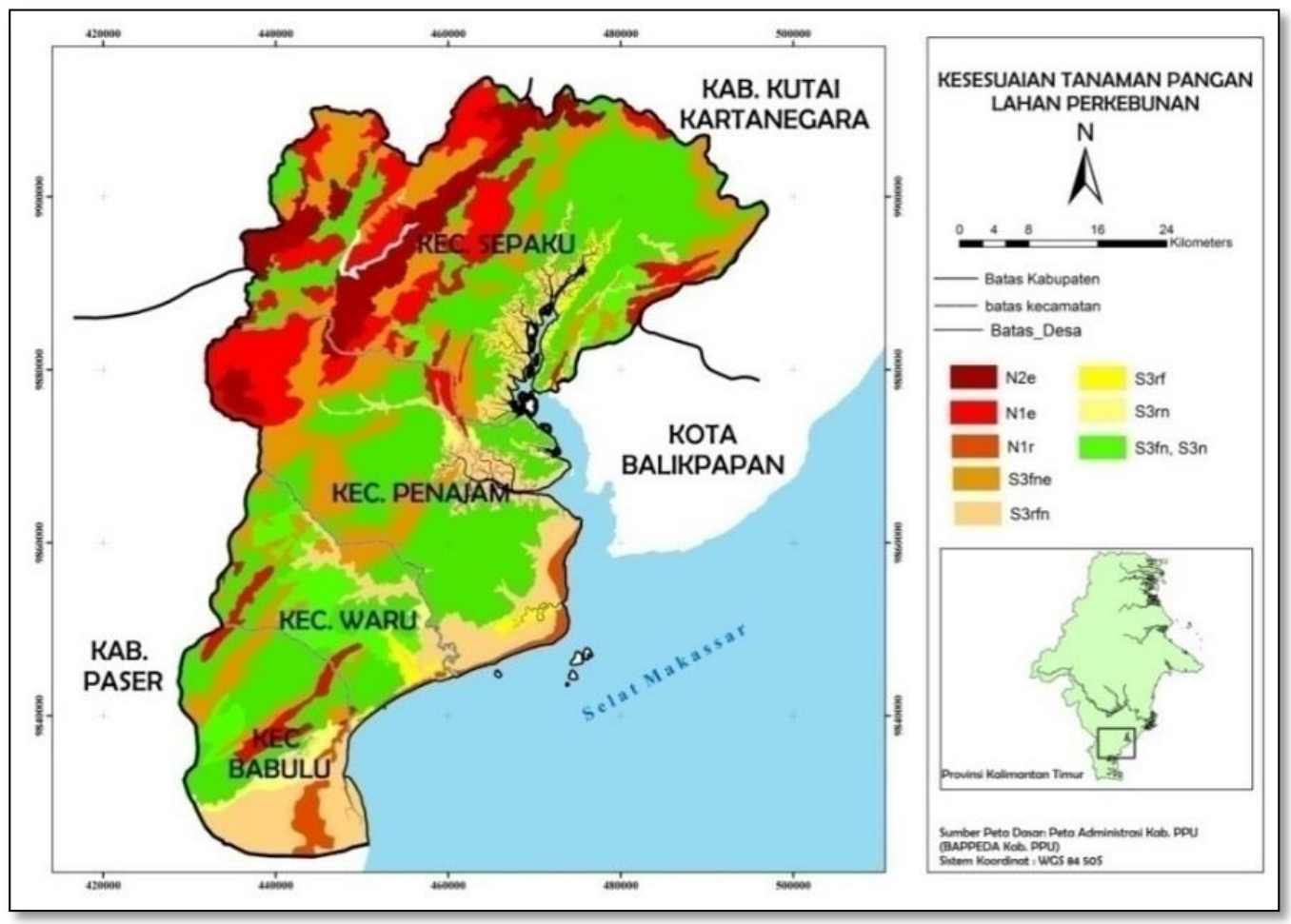

Gambar 7. Kesesuaian lahan untuk tanaman perkebunan 
Kecamatan Sepaku merupakan kecamatan dengan luas wilayah terbesar yang memiliki kelas kesesuaian S3fn yaitu 49,947 ha diikuti oleh Kecamatan Penajam (38,438 ha), Kecamatan Babulu (16,766 ha) dan Kecamatan Waru (13,925 ha). Desa Bumi Harapan dan Kelurahan Pemaluan merupakan wilayahwilayah di Kecamatan Sepaku dengan kelas S3fn yang terluas [Gambar 7]. Tanaman perkebunan khususnya tanaman kelapa sawit cenderung dapat beradaptasi dengan berbagai kondisi tanah. Faktor penting yang menentukan optimalisasi pertumbuhan kelapa sawit antara lain kedalaman solum $(>50 \mathrm{~cm})$ dan kondisi drainase (Rhebergen et al. 2016). Drainase buruk dapat menghambat pertumbuhan tanaman kelapa sawit. Karakteristik fisik tanah lebih berpengaruh terhadap pertumbuhan tanaman ini karena relatif lebih sulit diperbaiki dengan tindakan pengelolaan.wilayah yang tidak sesuai (N) untuk tanaman perkebunan seluas 64,384 ha dengan faktor pembatas erosi karena berada pada kelas lereng berbukit-bergunung.

\section{Arahan Pemanfaatan Ruang untuk Pertanian}

Proses pemanfaatan ruang merupakan wujud operasionalisasi rencana tata ruang atau pelaksanaan pembangunan. Arahan pemanfaatan ruang untuk pertanian pada kajian ini disusun secara deskriptif berdasarkan pertimbangan penggunaan lahan aktual, hierarki perkembangan wilayahdan kesesuaian lahan. Wilayah yang tidak tersedia untuk pertanian sebagian besar berada di Kecamatan Sepaku yaitu seluas 100,616 ha. Hal ini disebabkan sebagian besar wilayah di Kecamatan Sepaku (94,995 ha) termasuk dalam kawasan hutan. Wilayah-wilayah ini tidak diarahkan untuk pertanian meskipun penggunaan lahan aktualnya telah berupa pertanian (perkebunan) [Tabel 7].

Tabel 7. Arahan pemanfaatan ruang pertanian di Kabupaten Penajam Paser Utara

\begin{tabular}{llr}
\hline No & Uraian & Luas (ha) \\
\hline A & Tersedia untuk pertanian (A1+A2) & $\mathbf{1 6 2 , 4 7 9}$ \\
A1 & Sesuai untuk pertanian & 156,466 \\
& A1.1.Perkebunan prioritas I & 113,715 \\
& A1.2.Pangan lahan basah prioritas I & 24,224 \\
& A1.3.Pangan lahan kering & 15,201 \\
& A1.4.Perkebunan prioritas II & 3,045 \\
& A1.5 Pangan lahan basah prioritas II & 266 \\
A2 & Tidak sesuai untuk pertanian & 6,027 \\
B & Tidak tersedia untuk pertanian & $\mathbf{1 5 5 , 6 2 9}$ \\
\hline Jumlah (A+B) & $\mathbf{3 1 8 , 1 0 8}$ \\
\hline
\end{tabular}

Penggunaan lahan aktual menjadi pertimbangan kedua dalam merumuskan arahan pemanfaatan untuk pertanian. Wilayah dengan penggunaan lahan aktual berupa kawasan terbangun (built up area) dan tubuh air tidak dimasukkan dalam arahan. Wilayah-wilayah dengan penggunaan lahan aktual berupa pertanian seperti sawah, tegalan, perkebunan dan kebun campuran tetap dipertahankan apapun jenis kesesuaian lahan dan tingkat perkembangan wilayahnya. Faktor biaya dan efisiensi menjadi pertimbangan dalam merumuskan arahan pemanfaatan pertanian. Adapun rekomendasi yang diberikan pada wilayah-wilayah ini adalah intensifikasi melalui sejumlah tindakan perbaikan.

Wilayah-wilayah yang dapat diarahkan untuk ekstensifikasi atau pengembangan pertanian adalah penggunaan lahan semak, hutan dan tanah terbuka. Ketiga jenis penggunaan lahan ini berpotensi untuk pengembangan lahan-lahan baru untuk pertanian baik untuk tanaman pangan lahan basah, tanaman pangan lahan kering maupun perkebunan mengacu pada hasil evaluasi lahan. Apabila terdapat tumpang tindih hasil kesesuaian lahan maka priortitas akan diarahkan pada tanaman pangan sebagaimana rencana 
pengembangan pertanian Kabupaten Penajam Paser Utara (Rahman et al. 2015).Berdasarkan arahan pemanfaatan yang disusun didapatkan wilayah seluas 24,224 ha yang diarahkan untuk tanaman pangan lahan basah prioritas I [Tabel 7]. Potensi pengembangan lahan pertanian tanaman pangan lahan basah berada di Desa Labangka dan Desa Sebakung Jaya Kecamatan Babulu. Perkembangan tanaman pangan lahan kering cukup menjanjikan dan termasuk dalam arahan pengembangan komoditas pertanian di kabupaten ini. Arahan pemanfaatan untuktanaman pangan kering seluruhnya dimasukkan dalam prioritas I seluas 15,201 ha mengingat luasnya yang tidak sebesar tanaman lain. Wilayah seluas 6,308 ha merupakan penggunaan lahan aktual berupa tegalan. Terdapat wilayah seluas 8,893 ha yang berpotensi untuk pengembangan kawasan pertanian tanaman pangan lahan kering baru yaitu di Kelurahan Gunung Steleng, Kelurahan Buluminung di Kecamatan Penajam dan Desa Api-api di Kecamatan Waru [Gambar 8].

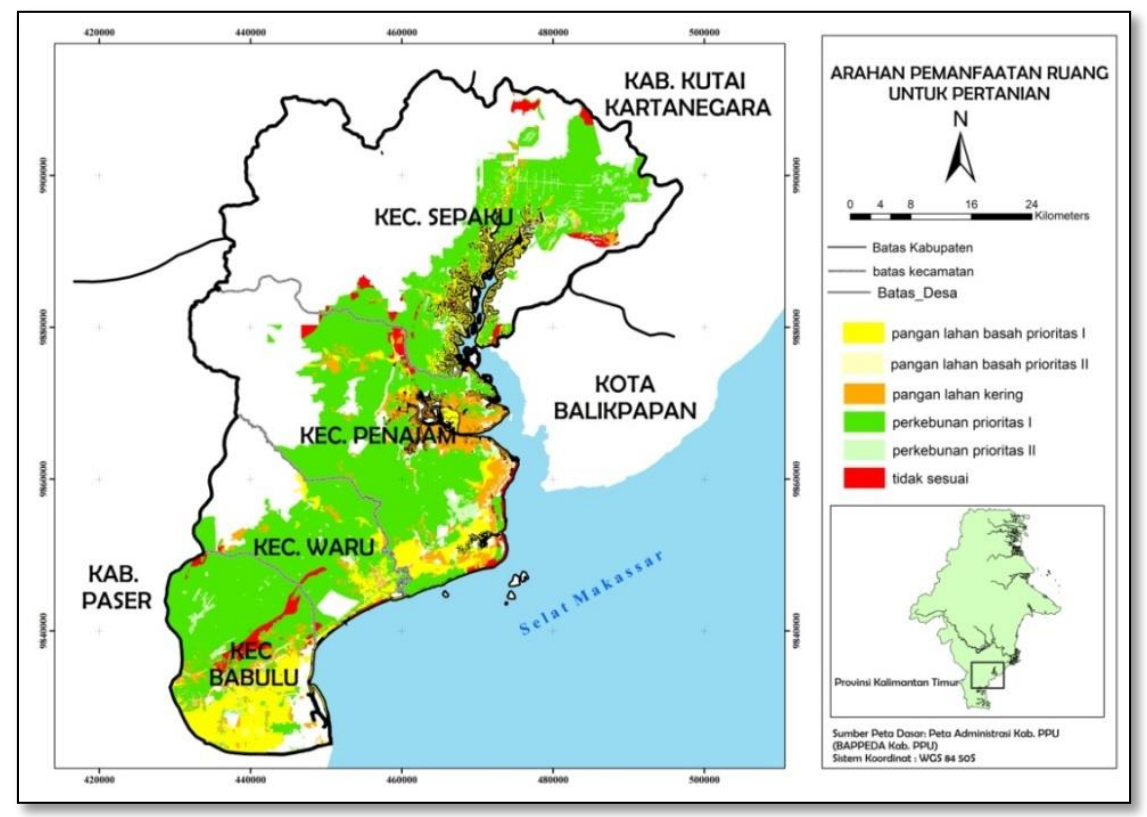

Gambar 8. Arahan pemanfaatan ruang untuk pertanian di KabupatenPenajam Paser Utara

Arahan pemanfaatan untuk perkebunan tersebar di seluruh wilayah kabupaten dengan proporsi luasan terbesar berada di Kecamatan Penajam (39,707 ha), Kecamatan Sepaku (30,273 ha), Kecamatan Babulu (23,337 ha) dan Kecamatan Waru (20,399 ha). Kelurahan Waru di Kecamatan Waru merupakan dua wilayah yang berpotensi untuk dikembangkan menjadi perkebunan prioritas I. Tingginya tingkat perubahan penggunaan lahan pada wilayah berhierarki tinggi menjadi pertimbangan dalam merumuskan prioritas arahan, sehingga wilayah-wilayah tersebut berada pada prioritas II. Arahan pemanfaatan ruang menjadikan pengembangan sektor pertanian di Kabupaten Penajam Paser Utara memudahkan dalam pengelolaan dan diharapkan dapat meningkatkan produktivitas serta keuntungan di wilayah tersebut. Pada akhirnya perkembangan sektor pertanian diharapkan dapat mendorong multiplier effect atau efek berganda di suatu wilayah (Nashiha et al. 2015). Berdasarkan arahan yang disusun terlihat bahwa pertanian tanaman pangan dipusatkan di Kecamatan Babulu dan Waru, sementara untuk tanaman perkebunan diarahkan pada Kecamatan Penajam dan Sepaku.

Penempatan arahan pertanian pada wilayah-wilayah cukup berkembang dan kurang berkembang (hierarki III) diharapkan dapat memacu pertumbuhan dan perkembangan wilayah tersebut. Arahan pengembangan pada wilayah-wilayah kurang berkembang (hierarki III) menurut Supriadi et al. (2014) antara lain 
melalui pengembangan jumlah dan jenis usaha rumahtangga dan industri kecil/mikro, pemberian modal usaha maupun pendampingan, sehingga pembentukan koperasi menjadi hal yang sangat pentinguntuk diwujudkan. Peningkatan jumlah dan akses terhadap sarana/prasarana pendidikan, kesehatan dan ekonomi serta penataan lingkungan kumuh.

\section{SIMPULAN}

Penggunaan lahan di Kabupaten Penajam Paser Utara tahun 2016 didominasi oleh hutan, perkebunan, Hutan Tanaman Industri (HTI) dan semak. Hutan mengalami pengurangan luas terbesar yaitu seluas 4,528 ha $(1.42 \%)$ sementara perkebunan adalah penggunaan lahan yang paling banyak mengalami penambahan luas sejumlah 11,924 ha (3.55\%).Perubahan penggunaan lahan yang menonjol selama tahun 2010 hingga 2016 di Kabupaten Penajam Paser Utara adalah perubahan dari hutan menjadi semak dan perkebunan serta semak menjadi perkebunan. Perubahan penggunaan lahan dari pertanian lahan basah maupun lahan kering ke kawasan terbangun belum nyata terlihat.

Perkembangan wilayah ditandai dengan peningkatan nilai IPD rata-rata dari 21.72 (2011) menjadi 32.04 (2014). Sebagian besar desa/kelurahan (33 desa/kelurahan) di Kabupaten Penajam Paser Utara termasuk dalam hierarki III (kurang berkembang). Kesesuaian untuk tanaman pangan lahan basah, tanaman pangan lahan kering maupun tanaman perkebunan di kabupaten ini berada pada kelas S3-N2 (sesuai marjinal-tidak sesuai permanen) dengan faktor pembatas bahaya erosi (e), hambatan perakaran (r), retensi hara (f) dan hara tersedia (n). Luas wilayah yang tersedia untuk pertanian adalah 162,493 ha dengan rincian (a) seluas 113,796 ha diarahkan untuk perkebunan prioritas I (b) seluas 24,258 ha untuk tanaman pangan lahan basah prioritas I (c) seluas 15,101 ha untuk tanaman pangan lahan kering dan (d) seluas 6,037 ha tidak sesuai untuk penggunaan pertanian.

\section{UCAPAN TERIMA KASIH}

Ucapan terima kasih disampaikan kepada Pusat Pembinaan, Pendidikan danPelatihan Perencanaan (Pusbindiklatren) - Bappenas RI selaku pemberi dana penelitian.

\section{DAFTAR PUSTAKA}

Badan Pusat Statistik Kabupaten Penajam Paser Utara. (2016). Statistik Daerah Kabupaten Penajam Paser Utara 2016.

Badan Penelitian dan Pengembangan Pertanian. 2012. Evaluasi Lahan untuk Komoditas Pertanian.

Ekosafitri, K. H., Rustiadi, E. dan Yulianda, F. (2017). Pengembangan Wilayah Pesisir Pantai Utara Jawa Tengah Berdasarkan Infrastruktur Daerah: Studi Kasus Kabupaten Jepara. Journal of Regional and Rural Development Planning, 1(2), 145-157.

Food and Agriculture Organization. (2007). Land Evaluation Towards a Revised Framework. Rome: FAO-UN.

Hardjowigeno, S. \& Widiatmaka. (2015). Evaluasi Kesesuaian Lahan dan Perencanaan Tata Guna Tanah. Yogyakarta: Gadjah Mada University Press.

Indrayani, P., Mitani, Y., Djamaluddin, I., \& Ikemi, H. (2017). A GIS Based Evaluation of Land Use Changes and Ecological Connectivity Index. Journal of Geomatics and Planning, 4(1), 9-18.

Kurnianty, D.N., Rustiadi, E., \& Baskoro D. P. T. (2015). Land Use Projection for Spatial Plan Consistency in Jabodetabek. Indonesian Journal of Geography, 47(2), 124-131.

Lukman, A., Sutandi, A., \& Munibah, K. (2017). Arahan Pengembangan Perkebunan Teh (Camellia Sinensis (L.) O. Kuntze) Rakyat di Kabupaten Tasikmalaya. Journal of Regional and Rural Development Planning. 1(2), 158-173. 
Nashiha, M., Turmudi, \& Nahib, I. (2015). Arahan Peruntukan Ruang Kawasan Perkebunan dengan Menggunakan Pendekatan Sistem Lahan Studi Kasus: Kabupaten Lombok Tengah. Globe, 17(2), 181-188.

Nowar, W., Baskoro, D. P. T., \& Tjahjono, B. (2015). Analisis Kesesuaian Lahan Komoditas Unggulan dan Arahan Pengembangannya di Wilayah Kabupaten Cianjur. Tataloka, 17(2), 87-98.

Purwantiningdyah, D. N.\& Hidayanto M. (2015). Kajian Penerapan Pengelolaan Tanaman Terpadu Padi dan Keragaan Usaha Tani Padi Sawah di Kalimantan Timur. Prosiding. Seminar Nasional Masyarakat Biodiversiti Indonesia. Masyarakat Biodiversitas Indonesia, 1, 306-313.

Rahman, R., Baskoro, D. P. T, \& Tjahjono, B. (2015). Prospek Pengembangan Komoditas Perkebunan di Wilayah Boliyohuto Kabupaten Gorontalo. Tataloka, 17(4), 209-222.

Rhebergen, T., Fairhurst, T., Zingorea, S., Fisherd, M., Oberthüre, T., \& Whitbread, A. (2016). Climate, soil and land-use based land suitability evaluation for oilpalm production in Ghana. European Journal of Agronomy, 81, 1-14.

Rusdiana, O., Supijatno, Ardiyanto, Y. \& Widodo, C. E. (2017). Potensi Pengembangan Kehutanan dan Pertanian Kabupaten Mahakam Ulu, Provinsi Kalimantan Timur. Journal of Regional and Rural Development Planning, 1(2), 114-131.

Panuju, D. R. \& Rustiadi, E. (2013). Teknik Analisis Perencanaan Pengembangan Wilayah. Bogor: Departemen Ilmu Tanah dan Sumberdaya Lahan, Institut Pertanian Bogor.

Sadesmesli, I., Baskoro, D. P. T., \& Pravitasari, A. E. (2017). Daya Dukung Lahan dalam Perencanaan Tata Ruang dalam Perencanaan Tata Ruang Wilayah (Studi Kasus Kabupaten Blitar, Jawa Timur). Tataloka, 19(4), 1-12.
Singha,. \& Swain, K. C. (2016). Land Suitability Evaluation Criteria for Agricultural Crop Selection: A Review. Agricultural Reviews. 37(2), 125-132.

Supriadi, D., Purwoko, A. \& Mahalli, K. (2014). Analisis Potensi dan Arah Pengembangan Desa Pesisir di Kabupaten Batu Bara. Jurnal Ekonom, 17(3), 1-14.

Widiatmaka, Ambarwulan, W., Setiawan, Y., \& Walter, C. (2016). Assessing the Suitability and Availability of Land for Agriculture in Tuban Regency, East Java, Indonesia. Applied and Environmental Soil Science, 1, 1-13. 